\title{
GAMBARAN KONSUMSI ZAT GIZI ANAK UMUR 6 BULAN - 12 TAHUN DI INDONESIA
}

\author{
Yekti Widodo ${ }^{1,4}$, Sandjaja2,4, Edith Sumedi3,4 \\ ${ }^{1}$ Pusat Teknologi Intervensi Kesehatan Masyarakat \\ 2Pusat Teknologi Terapan Kesehatan dan Epidemiologi Klinik \\ 3Jurusan Gizi, Politeknik Kesehatan Kemenkes Jakarta II \\ 4Persatuan Ahli Gizi Indonesia (PERSAGI) \\ fat_han_an@yahoo.co.id
}

\begin{abstract}
ABSTRAK
Prevalensi gangguan gizi pada anak di Indonesia terutama stunting masih cukup tinggi dan menempati posisi kelima terbesar di dunia. Penyebab multi sektoral gangguan gizi termasuk makanan, kesehatan dan pola asuh. Di tingkat individu, penyebab langsung gangguan gizi tersebut adalah masih rendahnya kuantitas konsumsi makanan dan rendahnya kualitas bahan makanan yang dikonsumsi, serta adanya penyakit infeksi. Tulisan ini bertujuan untuk mengetahui konsumsi makanan anak di Indonesia. Studi SEANUTS dilakukan di 48 kabupaten di wilayah perkotaan dan perdesaan. Data tingkat kecukupan konsumsi zat gizi anak Indonesia umur 6 bulan-12 tahun diperoleh dengan metode recall $1 \times 24$ jam yang meliputi 3600 anak. Konversi bahan makanan yang dikonsumi ke dalam zat gizi dilakukan berdasarkan daftar komposisi bahan makanan Indonesia dan tingkat kecukupan konsumsi zat gizi dihitung berdasarkan AKG Indonesia. Hasilnya menunjukkan rata-rata tingkat kecukupan konsumsi energi, vitamin A, asam folat, vitamin C, kalsium, dan besi masih di bawah AKG (44-77\%), sedangkan rata-rata tingkat kecukupan konsumsi protein dan fosfor sudah di atas AKG (106-114\%). Rata-rata tingkat kecukupan konsumsi zat gizi tertinggi adalah kelompok umur 6-11 bulan dan terendah kelompok umur 912 tahun. Proporsi anak dengan tingkat konsumsi zat gizi di bawah AKG tertinggi pada kelompok umur 912 tahun dan terendah umur 6-11 bulan. Dapat disimpulkan bahwa anak-anak pada kelompok umur lebih tua, dengan ibu berpendidikan rendah, kuintil sosial ekonomi rendah, dan tinggal di perdesaan, mempunyai risiko lebih tinggi mengonsumsi zat gizi di bawah AKG.
\end{abstract}

Kata kunci: konsumsi zat gizi, AKG, anak Indonesia

\section{ABSTRACT}

\section{DIETARY INTAKE OF INDONESIAN CHILDREN 6 MONTH - 12 YEAR OF AGE}

The prevalence of undernutrition in Indonesia is still high. Stunting, one type of undernutrition with the highest prevalence is rank number five in the world. The multisectoral causes of undernutrition include food, health, and caring practices. At individual level, the immediate causes are inadequate and low quality of dietary intake and infectious disease. This SEANUTS study aimed to assess dietary intake among children in Indonesia. The study was conducted in 48 districts covering urban and rural areas of 3,600 children 6 month-12 years of age. Dietary intake was assessed by $1 \times 24$ hour dietary recall by trained nutritionists. Indonesian food composition tables were used to calculate nutrient contents and then compared the nutrient intakes to Indonesian recommended dietary allowances (RDA) to assess their adequacy. The overall results showed that the average intakes of energy, vitamin $A$, vitamin $C$, folate, iron, and calsium and phosphor were still below the RDA (44-77\%), while protein and phosphor were above the RDA (106-114\%). The inadequacy varies among age group, the older the children the more deficit of nutrient intake. The highest average intake was among children 6-11 month of age groups and lowest is among children 9-12 year of age. By using cut-off point of Indonesian RDA, there were still high proportion of children deficit in nutrient intakes. It is concluded that children of older age group, living with low maternal education, low socioeconomic status, and in rural area were significantly higher risk of deficit in nutrient intake below RDA.

Keywords: nutrient consumption, RDA, Indonesian children

\section{PENDAHULUAN}

$\mathrm{M}$ asalah kekurangan gizi anak $d$ Indonesia adalah masih tingginya prevalensi stunting, underweight, dan wasting. Prevalensi stunting anak balita Indonesia adalah stunting 37,2 persen, underweight 19,6 persen, dan wasting 12,1 persen. ${ }^{1}$ Stunting merupakan gangguan gizi kronis dan jumlah anak stunting di Indonesia 
menempati posisi kelima terbesar di dunia. ${ }^{2}$ Penyebab langsung gangguan gizi pada anakanak adalah konsumsi zat gizi yang tidak memadai dan penyakit infeksi. ${ }^{3}$

Riset Kesehatan Dasar 2010 menunjukkan bahwa 21,5-44,4 persen anak usia 2-12 tahun defisit konsumsi energi $(<70$ persen Angka Kecukupan Gizi, AKG) dan 16,3-30,8 persen defisit konsumsi protein ( $<80$ persen AKG). Tingkat konsumsi energi dan protein anak lakilaki dan perempuan di perkotaan dan perdesaan tidak berbeda. ${ }^{4}$ Penelitian di Bandung menunjukkan bahwa rata-rata tingkat konsumsi mineral kalsium, besi, dan zink pada anak sekolah dasar masing-masing adalah 22 persen, 111 persen, dan 63 persen dari AKG. ${ }^{5}$ Penelitian pada anak sekolah dasar di Bolaang Mongondow Utara menunjukkan proporsi anak dengan tingkat konsumi besi di bawah AKG sebesar 40,9 persen, tingkat konsumsi protein di bawah AKG 31,8 persen, dan tingkat konsumsi vitamin $C$ di bawah AKG 21,8 persen. ${ }^{6}$ Pada anak usia $12-23$ bulan yang masih mendapat ASI rata-rata tingkat konsumsi energi, protein, dan zink dari makanan pendamping ASI masing-masing adalah 30 persen, 45 persen, dan 5 persen dari AKG. ${ }^{7}$

Hasil penelitian tersebut menunjukkan bahwa tingkat kecukupan konsumsi zat gizi anak usia 2-12 tahun di Indonesia masih cukup rendah. Data prevalensi stunting, wasting, dan underweight anak Indonesia masih tinggi. Hal tersebut merupakan salah satu indikasi anak Indonesia yang mengonsumsi zat gizi dalam jumlah tidak memadai (di bawah AKG) masih tinggi. Penyebab langsung status gizi anak adalah kurang tingkat konsumsi zat gizi dan infeksi penyakit. Data tingkat konsumsi zat gizi yang diperoleh melalui recall 1×24 jam secara langsung tidak dapat dikaitkan dengan prevalensi stunting, wasting, dan underweight namun tingkat konsumsi zat gizi merupakan informasi yang sangat bermanfaat sebagai informasi dini adanya kekurangan gizi serta bermanfaat dalam menyusun rencana intervensi peningkatan status gizi masyarakat. Artikel ini bertujuan memberikan informasi tentang gambaran tingkat konsumsi zat gizi serta faktorfaktor yang berhubungan dengan tingkat konsumsi zat gizi anak usia 6 bulan-12 tahun di Indonesia.

\section{METODE PENELITIAN}

Artikel ini disusun berdasarkan data penelitian SEANUTS Indonesia yang mencakup 48 kabupaten di seluruh Indonesia. Berdasarkan umur, sampel dikelompokkan menjadi 5 kelompok umur, yaitu: 6-11 bulan, 1-2 tahun, 3-5 tahun, 6-8 tahun, dan 9-12 tahun. Data konsumsi zat gizi dikumpulkan melalui recall 1x24 jam dan dikumpulkan oleh ahli gizi yang sudah dilatih serta dilakukan supervisi pada saat pengumpulan data. Setiap tim dibekali dengan timbangan makanan untuk menimbang berat makanan sesuai porsi yang dikonsumsi anak serta dibekali uang untuk membeli contoh makanan lokal yang dikonsumsi anak dan ditimbang berat makanan lokal tersebut. Konsumsi suplemen juga dikumpulkan tetapi tidak dimasukkan dalam analisis zat gizi. Pada anak usia di bawah 2 tahun yang masih disusui ditambahkan dengan zat gizi dari konsumsi ASI, berdasarkan estimasi volume ASI yang dikonsumsi sesuai dengan kelompok umur anak ${ }^{8}$ serta kandungan zat gizi $A S I^{9}$, agar dapat dibandingkan dengan AKG. Sebelum dianalisis data dilakukan proses cleaning data. Analisis konsumsi zat gizi dilakukan menggunakan program Nutrisoft. ${ }^{10}$ berdasarkan kandungan zat gizi menurut Daftar Komposisi Bahan Makanan Indonesia. ${ }^{11}$

Tingkat konsumsi zat gizi dianalisis berdasarkan Angka Kecukupan Gizi (AKG) Indonesia 2004. Tingkat kecukupan energi dan protein dalam artikel ini adalah 70 persen dan 80 persen dari AKG Indonesia, sedangkan untuk zat gizi lainnya adalah 100 persen AKG.12 Analisis statistik data konsumsi zat gizi dilakukan pembobotan (weighted) berdasarkan jumlah populasi dan sampel di setiap kabupaten. Konsumsi zat gizi dilakukan analisis secara deskriptif menurut kelompok umur, jenis kelamin, area tempat tinggal, tingkat pendidikan ibu, dan kuintil kepemilikan aset. Faktor-faktor yang berkorelasi dengan tingkat konsumsi zat gizi anak dianalisis dengan uji statistik MannWhitney $U$ dan Kruskal Wallis Test. Metode lengkap penelitian SEANUTS dapat dilihat pada artikel lain dalam jurnal ini. 
Tabel 1

Rata-rata Persentase Tingkat Konsumsi Zat Gizi terhadap AKG menurut Jenis Kelamin dan Area Tempat Tinggal

\begin{tabular}{|c|c|c|c|c|c|}
\hline \multirow{3}{*}{ Konsumsi Zat Gizi } & \multicolumn{4}{|c|}{ Persentase Terhadap AKG } & \multirow{3}{*}{ Tota } \\
\hline & \multicolumn{2}{|c|}{ Jenis Kelamin } & \multicolumn{2}{|c|}{ Tempat Tinggal } & \\
\hline & Laki-laki & Perempuan & Perkotaan & Perdesaan & \\
\hline Energi* & 79,0 & 75,4 & 84,0 & 71,3 & 77,2 \\
\hline Protein** & 108,0 & 104,0 & 119,0 & 94,6 & 106,0 \\
\hline Vitamin A & 67,8 & 68,6 & 72,8 & 64,1 & 68,2 \\
\hline Asam Folat & 45,1 & 44,7 & 49,4 & 41,0 & 44,9 \\
\hline Vitamin C & 43,4 & 44,1 & 50,5 & 37,8 & 43,7 \\
\hline Kalsium & 77,2 & 73,1 & 87,0 & 64,8 & 75,2 \\
\hline Fosfor & 117,2 & 111,7 & 130,9 & 100,0 & 114,4 \\
\hline Besi & 67,6 & 62,9 & 74,7 & 56,9 & 65,3 \\
\hline
\end{tabular}

* $<70 \%$ AKG $\quad * *<80 \%$ AKG

\section{HASIL}

Hasil analisis jenis konsumsi zat gizi yang disajikan dalam artikel ini meliputi energi (kkal), protein $(\mathrm{g})$, vitamin $A(R E)$, asam folat $(\mu \mathrm{g})$, vitamin $\mathrm{C}(\mathrm{mg})$, kalsium $(\mathrm{mg})$, fosfor $(\mathrm{mg})$, dan besi $(\mathrm{mg})$. Data konsumsi zat gizi disajikan dalam bentuk rata-rata tingkat kecukupan konsumsi zat gizi terhadap AKG (\%) dan proporsi anak dengan tingkat konsumsi zat gizi di bawah AKG (\%). Pada anak umur 6 bulan 12 tahun rata-rata tingkat konsumsi zat gizi energi, protein, vitamin $A$, asam folat, vitamin $C$, kalsium, fosfor, dan besi terhadap AKG berturut-turut adalah 77,2 persen, 106,0 persen, 68,2 persen, 44,9 persen, 43,7 persen, 75,2 persen, 114,4 persen, dan 65,3 persen. Ratarata persentase tingkat konsumsi ke-8 zat gizi tersebut terhadap AKG menurut karakteristik sampel disajikan pada Tabel 1.

Pada Tabel 2 disajikan data rata-rata tingkat konsumsi zat gizi menuruk kelompok umur, area tempat tinggal, tingat pendidikan ibu, dan kuintil tingkat kepemilikan aset. Data tabel 2 menunjukkan rata-rata tingkat konsumsi energi di atas AKG hanya pada kelompok umur 6-11 bulan, sedangkan pada kelompok umur 1-12 tahun masih di bawah AKG. Rata-rata tingkat konsumsi protein di atas AKG terdapat pada kelompok 6 bulan - 5 tahun. Pada kelompok umur 6-12 tahun rata-rata tingkat konsumsi energi, protein, masih di bawah AKG. Hasil uji statistik menunjukkan bahwa tingkat konsumsi energi dan protein antar kelompok umur berbeda nyata. Ada kecenderungan makin tinggi kelompok umur tingkat konsumsi energi dan protein makin rendah. Menurut kelompok umur rata-rata tingkat konsumsi zat gizi tertinggi adalah kelompok umur 6-11 bulan dan terendah 9-12 tahun.

Tingkat konsumsi energi dan protein pada anak laki-laki relatif lebih tinggi daripada anak perempuan. Secara statistik perbedaan ratarata tingkat konsumsi energi antara anak lakilaki dan perempuan berbeda sedangkan protein tidak berbeda. Tingkat konsumsi energi dan protein anak umur 6 bulan - 12 tahun di perdesaan lebih rendah daripada di perkotaan dan secara statistik berbeda nyata. Ada kecenderungan makin tinggi tingkat pendidikan ibu dan kuintil tingkat kepemilkan aset makin tinggi, tingkat konsumsi energi dan protein dan secara statistik antar tingkat pendidikan ibu dan kuintil berbeda nyata. Rata-rata persentase tingkat konsumsi vitamin $\mathrm{A}$, asam folat, dan vitamin $C$ terhadap AKG menurut karakteristik sampel disajikan pada Tabel 3 .

Tabel 3 menunjukkan bahwa rata-rata tingkat konsumsi vitamin $\mathrm{A}$ dan vitamin $\mathrm{C}$ di atas AKG hanya pada kelompok umur 6-11 bulan. Rata-rata tingkat konsumsi asam folat pada semua kelompok umur 6 bulan - 12 tahun masih di bawah AKG. Ada kecenderungan makin tinggi kelompok umur rata-rata tingkat konsumsi vitamin $A$, asam folat dan vitamin $C$ makin rendah. Secara statistik rata-rata tingkat konsumsi vitamin $\mathrm{A}$, asam folat dan vitamin $\mathrm{C}$ antar kelompok umur berbeda nyata.

Tingkat konsumsi vitamin $\mathrm{A}$ dan vitamin $\mathrm{C}$ pada anak laki-laki relatif lebih rendah, 
sedangkan asam folat relatif lebih tinggi pada anak laki-laki daripada anak perempuan dan secara statistik tidak berbeda antara laki-laki dan perempuan. Rata-rata tingkat konsumsi vitamin $A$, asam folat, dan vitamin $C$ di perdesaan lebih rendah daripada di perkotaan dan secara statistik berbeda nyata. Ada kecenderungan makin tinggi tingkat pendidikan ibu dan kuintil tingkat kepemilkan aset makin tinggi rata-rata tingkat konsumsi vitamin $\mathrm{A}$, asam folat, dan vitamin $C$ dan secara statistik ada perbedaan nyata antar tingkat pendidikan ibu dan antar kuintil. Rata-rata persentase tingkat konsumsi kalsium, fosfor dan besi terhadap AKG menurut karakteristik sampel disajikan pada Tabel 4.

Tabel 4 menunjukkan bahwa rata-rata tingkat konsumsi kalsium pada anak kelompok umur 6-11 bulan sudah di atas AKG, sedangkan kelompok umur 1-12 tahun masih di bawah AKG. Rata-rata tingkat konsumsi fosfor pada kelompok umur 6 bulan - 8 tahun sudah di atas AKG sedangkan kelompok umur 9-12 tahun masih di bawah AKG. Ada kecenderungan makin tinggi kelompok umur rata-rata tingkat konsumsi kalsium, fosfor, dan besi makin rendah. Secara statistik rata-rata tingkat konsumsi kalsium, fosfor, dan besi antar kelompok umur berbeda nyata.

Tingkat konsumsi kalsium, fosfor, dan besi pada anak laki-laki relatif lebih tinggi daripada anak perempuan. Secara statistik rata-rata tingkat konsumsi kalsium dan fosfor tidak berbeda antara laki-laki dan perempuan, sedangkan rata-rata tingkat konsumsi besi antara laki-laki dan perempuan berbeda nyata. Rata-rata tingkat konsumsi kalsium, fosfor, dan besi di perdesaan lebih rendah daripada di perkotaan dan secara statistik berbeda nyata. Ada kecenderungan makin tinggi tingkat pendidikan ibu dan kuintil tingkat kepemilkan aset rata-rata tingkat konsumsi kalsium, fosfor, dan besi makin tinggi, dan secara statistik ada perbedaan nyata antar tingkat pendidikan ibu dan antar kuintil. Proporsi anak dengan tingkat konsumsi zat gizi di bawah AKG menurut karakteristik sampel disajikan pada Tabel 5.

Tabel 2

Rata-rata Persentase Tingkat Konsumsi Energi dan Protein terhadap AKG menurut Karakteristik Sampel

\begin{tabular}{|c|c|c|c|c|c|c|}
\hline \multirow{3}{*}{$\begin{array}{l}\text { Karakteristik } \\
\text { Sampel }\end{array}$} & \multicolumn{6}{|c|}{ Persentase Terhadap AKG } \\
\hline & \multicolumn{3}{|c|}{ Energi* $^{*}$} & \multicolumn{3}{|c|}{ Protein $^{* *}$} \\
\hline & Rata-rata & SE & $\mathrm{p}$ & Rata-rata & SE & $p$ \\
\hline \multicolumn{7}{|l|}{ Kelompok umur } \\
\hline 6-11 bulan & 116,3 & 3,11 & \multirow[t]{5}{*}{$0,000^{1}$} & 115,3 & 5,29 & \multirow[t]{5}{*}{$0,000^{1}$} \\
\hline $1-2$ tahun & 91,4 & 1,67 & & 122,2 & 2,81 & \\
\hline 3-5 tahun & 82,3 & 1,22 & & 116,7 & 2,08 & \\
\hline 6-8 tahun & 69,5 & 0,80 & & 98,4 & 1,24 & \\
\hline 9-12 tahun & 61,5 & 0,84 & & 88,8 & 1,35 & \\
\hline \multicolumn{7}{|l|}{ Jenis kelamin } \\
\hline Laki-laki & 79,0 & 0,86 & \multirow[t]{2}{*}{$0,045^{2}$} & 108,0 & 1,33 & \multirow[t]{2}{*}{$0,086^{2}$} \\
\hline Perempuan & 75,4 & 0,83 & & 104,0 & 1,30 & \\
\hline \multicolumn{7}{|l|}{ Area tempat tinggal } \\
\hline Perkotaan & 84,0 & 0,94 & \multirow[t]{2}{*}{$0,000^{2}$} & 119,0 & 1,50 & \multirow[t]{2}{*}{$0,000^{2}$} \\
\hline Perdesaan & 71,3 & 0,72 & & 94,6 & 1,08 & \\
\hline \multicolumn{7}{|c|}{ Tingkat pendidikan ibu } \\
\hline Tidak/Tamat SD & 69,6 & 0,71 & \multirow[t]{4}{*}{$0,000^{1}$} & 92,9 & 1,05 & \multirow[t]{4}{*}{0,000} \\
\hline Tamat SMP & 79,0 & 1,26 & & 106,1 & 1,94 & \\
\hline Tamat SMA & 89,3 & 1,46 & & 128,0 & 2,29 & \\
\hline Tamat PT & 92,4 & 2,92 & & 140,7 & 5,02 & \\
\hline \multicolumn{7}{|c|}{ Tingkat kepemilikan aset } \\
\hline Kuintil 1 & 67,7 & 1,03 & \multirow[t]{5}{*}{$0,000^{1}$} & 87,7 & 1,45 & \multirow[t]{5}{*}{$0,000^{1}$} \\
\hline Kuintil 2 & 73,0 & 1,31 & & 95,1 & 1,90 & \\
\hline Kuintil 3 & 76,4 & 1,16 & & 106,0 & 1,85 & \\
\hline Kuintil 4 & 84,3 & 1,45 & & 117,9 & 2,21 & \\
\hline Kuintil 5 & 89,0 & 1,66 & & 132,0 & 2,73 & \\
\hline
\end{tabular}


Tabel 3

Rata-rata Persentase Tingkat Konsumsi Vitamin A, Asam Folat, dan Vitamin C terhadap AKG menurut Karakteristik Sampel

\begin{tabular}{|c|c|c|c|c|c|c|c|c|c|}
\hline \multirow{3}{*}{$\begin{array}{l}\text { Karakteristik } \\
\text { Sampel }\end{array}$} & \multicolumn{9}{|c|}{ Persentase Terhadap AKG } \\
\hline & \multicolumn{3}{|c|}{ Vitamin A } & \multicolumn{3}{|c|}{ Asam Folat } & \multicolumn{3}{|c|}{ Vitamin C } \\
\hline & $\begin{array}{l}\text { Rata- } \\
\text { rata }\end{array}$ & SE & $p$ & $\begin{array}{l}\text { Rata- } \\
\text { rata }\end{array}$ & SE & $p$ & $\begin{array}{l}\text { Rata- } \\
\text { rata }\end{array}$ & SE & $p$ \\
\hline \multicolumn{10}{|l|}{ Kelompok umur } \\
\hline 6-11 bulan & 110,2 & 3,83 & $0,000^{1}$ & 79,0 & 4,29 & $0,000^{1}$ & 110,9 & 4,26 & $0,000^{1}$ \\
\hline $1-2$ tahun & 80,7 & 2,05 & & 50,5 & 1,49 & & 66,0 & 2,80 & \\
\hline 3-5 tahun & 68,0 & 1,47 & & 46,3 & 1,13 & & 40,9 & 1,85 & \\
\hline $6-8$ tahun & 64,9 & 1,20 & & 42,4 & 0,95 & & 32,0 & 1,32 & \\
\hline 9-12 tahun & 52,9 & 1,17 & & 34,4 & 1,11 & & 30,3 & 1,41 & \\
\hline \multicolumn{10}{|l|}{ Jenis kelamin } \\
\hline Laki-laki & 67,8 & 1,07 & $0,119^{2}$ & 45,1 & 0,85 & $0,594^{2}$ & 43,4 & 1,33 & $0,156^{2}$ \\
\hline Perempuan & 68,6 & 1,03 & & 44,7 & 0,85 & & 44,1 & 1,33 & \\
\hline \multicolumn{10}{|c|}{ Area tempat tinggal } \\
\hline Perkotaan & 72,8 & 1,18 & $0,000^{2}$ & 49,4 & 1,02 & $0,000^{2}$ & 50,5 & 1,52 & $0,000^{2}$ \\
\hline Perdesaan & 64,1 & 0,93 & & 41,0 & 0,67 & & 37,8 & 1,14 & \\
\hline \multicolumn{10}{|c|}{ Tingkat pendidikan ibu } \\
\hline Tidak/Tamat SD & 61,6 & 0,89 & $0,000^{1}$ & 40,0 & 0,69 & $0,000^{1}$ & 33,7 & 1,08 & $0,000^{1}$ \\
\hline Tamat SMP & 71,2 & 1,69 & & 45,3 & 1,31 & & 42,6 & 1,72 & \\
\hline Tamat SMA & 75,7 & 1,72 & & 53,5 & 1,51 & & 60,5 & 2,52 & \\
\hline Tamat PT & 87,0 & 4,29 & & 55,1 & 3,53 & & 75,0 & 5,49 & \\
\hline \multicolumn{10}{|c|}{ Tingkat kepemilikan aset } \\
\hline Kuintil 1 & 60,9 & 1,25 & $0,000^{1}$ & 37,6 & 0,94 & $0,000^{1}$ & 29,7 & 1,38 & $0,000^{1}$ \\
\hline Kuintil 2 & 64,4 & 1,58 & & 41,2 & 1,26 & & 35,9 & 1,77 & \\
\hline Kuintil 3 & 68,9 & 1,66 & & 47,2 & 1,34 & & 41,7 & 1,97 & \\
\hline Kuintil 4 & 72,1 & 1,86 & & 49,9 & 1,40 & & 54,7 & 2,44 & \\
\hline Kuintil 5 & 77,7 & 2,05 & & 51,5 & 1,81 & & 63,4 & 2,86 & \\
\hline
\end{tabular}

Tabel 5 menunjukkan bahwa proporsi sampel dengan konsumsi energi, vitamin $A$, asam folat, vitamin $C$, dan kalsium di bawah AKG, terendah pada kelompok umur 6-11 bulan dan tertinggi pada kelompok umur 9-12 tahun. Ada kecenderungan makin tua kelompok umur, proporsi anak dengan konsumsi energi, vitamin $A$, asam folat, vitamin $C$, dan kalsium di bawah AKG makin tinggi. Proporsi sampel dengan konsumsi protein, fosfor, dan besi di bawah AKG terendah adalah kelompok umur 3-5 tahun, 6-8 tahun, dan 1-2 tahun. Proporsi sampel dengan konsumsi energi, protein, vitamin $A$, asam folat, vitamin $C$, kalsium, fosfor, dan besi di bawah AKG tertinggi pada kelompok umur 9-12 tahun.

Proporsi sampel dengan konsumsi energi, protein, asam folat, kalsium, fosfor, dan besi di bahwa AKG relatif lebih tinggi pada anak perempuan daripada anak laki-laki, sedangkan vitamin $\mathrm{A}$ dan vitamin $\mathrm{C}$ relatif lebih tinggi pada anak laki-laki. Proposi sampel dengan konsumsi energi, protein, vitamin $A$, asam folat, vitamin $C$, kalsium, fosfor, dan besi di bawah AKG lebih tinggi di perdesaan daripada di perkotaan. Ada kencenderungan makin tinggi tingkat pendidikan ibu dan kuintil kepemilikan aset, proporsi sampel dengan konsumsi zat gizi di bawah AKG makin rendah.

Tabel 6 menyajikan hasil analisis regresi logistik terhadap faktor risiko konsumsi zat gizi di bawah AKG. Data tersebut menunjukkan bahwa risiko konsumsi energi, protein, asam folat, kalsium, fosfor, dan besi di bawah AKG lebih besar terjadi pada anak-anak pada kelompok umur lebih tua, tinggal di perdesaan, dengan ibu berpendidikan rendah, dan kuintil rendah. 
Tabel 4

Rata-rata Persentase Tingkat Konsumsi Kalsium, Fosfor, dan Besi Terhadap AKG Menurut Karakteristik Sampel

\begin{tabular}{|c|c|c|c|c|c|c|c|c|c|}
\hline \multirow{3}{*}{$\begin{array}{l}\text { Karakteristik } \\
\text { Sampel }\end{array}$} & \multicolumn{9}{|c|}{ Persentase Terhadap AKG } \\
\hline & \multicolumn{3}{|c|}{ Kalsium } & \multicolumn{3}{|c|}{ Fosfor } & \multicolumn{3}{|c|}{ Besi } \\
\hline & $\begin{array}{c}\text { Rata- } \\
\text { rata }\end{array}$ & SE & $p$ & $\begin{array}{l}\text { Rata- } \\
\text { rata }\end{array}$ & SE & $p$ & $\begin{array}{l}\text { Rata- } \\
\text { rata }\end{array}$ & SE & $p$ \\
\hline \multicolumn{10}{|l|}{ Kelompok umur } \\
\hline 6-11 bulan & 112,1 & 6,50 & \multirow[t]{5}{*}{$0,000^{1}$} & 151,8 & 9,41 & \multirow[t]{5}{*}{$0,000^{1}$} & 54,7 & 4,59 & \multirow[t]{5}{*}{$0,000^{1}$} \\
\hline $1-2$ tahun & 94,5 & 3,46 & & 120,8 & 4,01 & & 75,1 & 2,49 & \\
\hline 3-5 tahun & 84,8 & 2,12 & & 126,2 & 2,54 & & 70,7 & 1,46 & \\
\hline $6-8$ tahun & 69,3 & 1,19 & & 122,8 & 1,68 & & 67,2 & 0,96 & \\
\hline 9-12 tahun & 47,5 & 1,06 & & 73,8 & 1,78 & & 49,8 & 1,02 & \\
\hline \multicolumn{10}{|l|}{ Jenis kelamin } \\
\hline Laki-laki & 77,2 & 1,45 & \multirow[t]{2}{*}{$0,082^{2}$} & 117,2 & 1,83 & \multirow[t]{2}{*}{$0,070^{2}$} & 67,6 & 1,03 & \multirow[t]{2}{*}{$0,000^{2}$} \\
\hline Perempuan & 73,1 & 1,44 & & 111,7 & 1,82 & & 62,9 & 1,05 & \\
\hline \multicolumn{10}{|l|}{ Area tempat tinggal } \\
\hline Perkotaan & 87,0 & 1,79 & \multirow[t]{2}{*}{$0,000^{2}$} & 130,9 & 2,22 & \multirow[t]{2}{*}{$0,000^{2}$} & 74,7 & 1,25 & \multirow[t]{2}{*}{$0,000^{2}$} \\
\hline Perdesaan & 64,8 & 1,04 & & 100,0 & 1,36 & & 56,9 & 0,79 & \\
\hline \multicolumn{10}{|c|}{ Tingkat pendidikan ibu } \\
\hline Tidak/Tamat SD & 61,1 & 0,95 & \multirow[t]{4}{*}{$0,000^{1}$} & 96,1 & 1,29 & \multirow[t]{4}{*}{$0,000^{1}$} & 55,5 & 0,75 & \multirow[t]{4}{*}{$0,000^{1}$} \\
\hline Tamat SMP & 73,6 & 1,75 & & 111,0 & 2,23 & & 64,6 & 1,38 & \\
\hline Tamat SMA & 100,3 & 2,98 & & 148,9 & 3,68 & & 82,0 & 2,01 & \\
\hline Tamat PT & 113,1 & 7,40 & & 163,1 & 8,39 & & 92,9 & 4,99 & \\
\hline \multicolumn{10}{|c|}{ Tingkat kepemilikan aset } \\
\hline Kuintil 1 & 57,1 & 1,26 & \multirow[t]{5}{*}{$0,000^{1}$} & 87,9 & 1,69 & \multirow[t]{5}{*}{$0,000^{1}$} & 52,7 & 1,04 & \multirow[t]{5}{*}{$0,000^{1}$} \\
\hline Kuintil 2 & 65,4 & 1,67 & & 99,7 & 2,26 & & 56,3 & 1,32 & \\
\hline Kuintil 3 & 74,0 & 2,00 & & 115,9 & 2,47 & & 65,4 & 1,45 & \\
\hline Kuintil 4 & 87,7 & 2,56 & & 132,4 & 3,19 & & 75,1 & 1,87 & \\
\hline Kuintil 5 & 100,2 & 3,63 & & 148,3 & 4,40 & & 82,7 & 2,39 & \\
\hline
\end{tabular}

Data Tabel 6 menunjukkan bahwa umur yang lebih muda (< 9-12 tahun) risiko yang memberikan proteksi terhadap konsumsi zat gizi di bawah AKG. Jadi pada kelompok umur < 912 tahun risiko konsumsi zat gizi dibawah AKG lebih rendah daripada risiko pada kelompok umur 9-12 tahun. Anak yang tinggal di perdesaan mempunyai risiko 1,265-2,149 kali lebih besar mengonsumsi zat gizi di bawah AKG daripada anak yang tinggal di perkotaan.

Tingkat pendidikan ibu yang rendah ( $\leq$ tamat SMP) dan kuintil rendah (kuintil 1) memberikan risiko sebesar 1,306-2,589 kali besar anak mengkonsumsi zat gizi di bawah AKG daripada pada anak dengan tingkat pendidikan ibu dan kuintil yang lebih tinggi.

\section{BAHASAN}

Rata-rata tingkat konsumsi protein $(106,0 \%)$ dan fosfor $(114,4 \%)$ pada anak umur 6 bulan - 12 tahun di Indonesia sudah di atas AKG (> 100\%). Rata-rata tingkat konsumsi energi juga sudah lebih dari 70 AKG $(77,2 \%)$, bahkan pada kelompok umur 6-11 bulan ratarata tingkat kecukupan konsumsi energi, protein, vitamin $A$, vitamin $C$, kalsium, dan fosfor lebih dari 100 persen AKG. Interpretasi data rata-rata tingkat kecukupan konsumsi zat gizi perlu dikaitkan dengan data proporsi anak yang mempunyai tingkat konsumsi zat gizi di bawah AKG. Data proporsi anak umur 6 bulan - 12 tahun dengan konsumsi zat gizi di bawah AKG ternyata masih tinggi (berkisar antara 30,8 $97,7 \%)$. 
Tabel 5

Proporsi Sampel yang Mengkonsumsi Zat Gizi di Bawah AKG menurut Karakteristik Sampel

\begin{tabular}{|c|c|c|c|c|c|c|c|c|}
\hline Karakteristik Sampel & Energi* & Protein** & $\begin{array}{c}\text { Vitamin } \\
\text { A }\end{array}$ & $\begin{array}{c}\text { Asam } \\
\text { Folat }\end{array}$ & $\begin{array}{l}\text { Vitamin } \\
\text { C }\end{array}$ & Kalsium & Fosfor & Besi \\
\hline \multicolumn{9}{|l|}{ Kelompok umur } \\
\hline 6-11 bulan & 4,9 & 36,4 & 42,0 & 80,2 & 56,8 & 61,1 & 42,0 & 84,0 \\
\hline 1-2 tahun & 34,8 & 30,7 & 72,5 & 91,4 & 79,0 & 68,8 & 56,0 & 76,2 \\
\hline 3-5 tahun & 42,1 & 30,2 & 81,5 & 95,1 & 88,3 & 72,4 & 41,6 & 84,0 \\
\hline $6-8$ tahun & 57,4 & 38,0 & 85,7 & 95,6 & 93,2 & 82,7 & 37,7 & 86,2 \\
\hline $9-12$ tahun & 69,1 & 44,7 & 92,8 & 97,7 & 94,7 & 93,8 & 76,5 & 94,9 \\
\hline \multicolumn{9}{|l|}{ Jenis kelamin } \\
\hline Laki-laki & 47,6 & 34,3 & 81,9 & 94,4 & 88,1 & 78,0 & 48,0 & 85,3 \\
\hline Perempuan & 51,4 & 37,9 & 81,5 & 94,5 & 87,9 & 79,9 & 52,5 & 85,9 \\
\hline \multicolumn{9}{|l|}{ Area tempat tinggal } \\
\hline Perkotaan & 43,4 & 26,5 & 77,8 & 91,7 & 83,4 & 72,0 & 41,6 & 79,8 \\
\hline Perdesaan & 54,7 & 44,6 & 85,1 & 96,9 & 92,1 & 85,0 & 57,8 & 90,6 \\
\hline \multicolumn{9}{|c|}{ Tingkat pendidikan ibu } \\
\hline Tidak/Tamat SD & 42,5 & 57,5 & 46,4 & 86,9 & 96,9 & 93,8 & 86,7 & 60,5 \\
\hline Tamat SMP & 52,3 & 47,7 & 34,1 & 79,7 & 95,4 & 89,0 & 78,9 & 49,4 \\
\hline Tamat SMA & 63,4 & 36,6 & 19,2 & 75,6 & 88,9 & 77,7 & 65,9 & 32,2 \\
\hline Tamat PT & 67,2 & 32,8 & 15,8 & 65,5 & 90,4 & 71,2 & 58,8 & 29,9 \\
\hline \multicolumn{9}{|c|}{ Tingkat kepemilikan aset } \\
\hline Kuintil 1 & 60,3 & 53,1 & 88,3 & 97,6 & 95,4 & 90,7 & 67,3 & 92,8 \\
\hline Kuintil 2 & 56,2 & 43,1 & 85,1 & 95,8 & 92,6 & 83,5 & 58,2 & 91,2 \\
\hline Kuintil 3 & 49,1 & 33,1 & 80,6 & 93,8 & 90,3 & 81,1 & 45,5 & 87,2 \\
\hline Kuintil 4 & 40,3 & 25,3 & 77,8 & 90,9 & 81,7 & 67,5 & 36,4 & 78,1 \\
\hline Kuintil 5 & 36,4 & 18,6 & 73,9 & 92,7 & 76,1 & 66,3 & 37,1 & 75,0 \\
\hline
\end{tabular}

Tabel 6

Odd Ratio Faktor Risiko Konsumsi Zat Gizi di Bawah AKG pada Anak Umur 6 Bulan - 12 Tahun

\begin{tabular}{|c|c|c|c|c|c|c|c|c|}
\hline $\begin{array}{l}\text { Karakteristik } \\
\text { Sampel }\end{array}$ & Energi* $^{\star}$ & Protein** & $\begin{array}{c}\text { Vitamin } \\
\text { A }\end{array}$ & $\begin{array}{l}\text { Asam } \\
\text { Folat }\end{array}$ & $\begin{array}{l}\text { Vitamin } \\
\text { C }\end{array}$ & Kalsium & Fosfor & Besi \\
\hline \multicolumn{9}{|l|}{ Umur } \\
\hline$<9-12$ tahun & 0,621 & 0,737 & 0,463 & 0,498 & 0,461 & 0,315 & 0,144 & 0,385 \\
\hline \multicolumn{9}{|c|}{ Area tempat Tinggal } \\
\hline Perdesaan & 1,265 & 1,512 & 1,304 & 2,149 & 1,457 & 1,714 & 1,343 & 1,835 \\
\hline \multicolumn{9}{|c|}{ Tingkat pendidikan ibu } \\
\hline$\leq$ Tamat SMP & 1,447 & 1,658 & - & 2,172 & 1,585 & 1,306 & 1,613 & 1,459 \\
\hline \multicolumn{9}{|c|}{ Tingkat kepemilikan aset } \\
\hline Kuintil 1 & 2,003 & 1,725 & 1,755 & - & 2,589 & - & 1,676 & 1,449 \\
\hline
\end{tabular}

Data Tabel 1, 2, 3, dan 4 menunjukkan ada kecenderungan pada kelompok umur muda rata-rata persentase tingkat konsumsi zat gizi terhadap AKG lebih tinggi dibandingkan kelompok umur yang lebih tua. Hal tersebut menunjukkan bahwa pada kelompok umur yang lebih tua adalah kelompok yang lebih rawan terjadi kekurangan konsumsi zat gizi. Proporsi sampel dengan konsumsi zat gizi di bawah AKG di daerah perdesaan lebih tinggi daripada perkotaan. Tingkat konsumsi zat gizi pada anak laki-laki dan perempuan juga menunjukkan 
perbedaan namun perbedaan yang nyata hanya pada konsumsi energi dan besi, dimana konsumsi pada anak perempuan lebih rendah. Hal tersebut menunjukkan bahwa kelompok umur, jenis kelamin, area tempat tinggal, tingkat pendidikan ibu, dan kuintil tingkat kepemilikan aset merupakan faktor risiko yang berkaitan dengan tingkat konsumsi zat gizi pada anak umur 6 bulan - 12 tahun.

Akar masalah rendahnya status gizi pada anak diantaranya adalah kemiskinan dan rendahnya tingkat pendidikan orang tua. ${ }^{3}$ Anak kekurangan gizi lebih banyak ditemukan pada keluarga miskin, berpendidikan rendah, dan tinggal di perdesaan. ${ }^{4}$ Berdasarkan kerangka konsep penyebab gangguan kekurangan gizi pada anak menunjukkan bahwa penyebab langsung rendahnya status gizi anak adalah konsumsi zat gizi yang tidak memadai dan infeksi penyakit. ${ }^{3}$ Konsumsi zat gizi pada anak usia 6 bulan - 12 tahun dipengaruhi oleh ketersediaan makanan dan pola asuh termasuk pola pemberian makan anak.

Pola kecukupan tingkat konsumsi energi, protein, vitamin $A$, asam folat, vitamin C, kalsium, fosfor dan besi anak di Indonesia sama dengan pola di negara berkembang lain. ${ }^{13}$ Ratarata tingkat konsumsi energi, vitamin $A$, asam folat, vitamin $C$, kalsium, dan besi pada umumnya masih di bawah AKG, sedangkan tingkat konsumsi protein dan fosfor, sudah di atas AKG. Tingkat kecukupan konsumsi zat gizi di daerah perdesaan lebih rendah daripada di perkotaan, hal tersebut berkaitan dengan fakta bahwa tingkat pendidikan dan tingkat ekonomi keluarga di perdesaan relatif lebih rendah daripada di perkotaan. Temuan tersebut sama dengan hasil Riskesdas 2010 yang menyatakan bahwa anak dengan konsumsi energi dan protein di bawah AKG lebih banyak ditemukan pada keluarga dengan pendidikan rendah, tingkat pendapatan rendah dan tinggal di perdesaan. ${ }^{4}$

Angka rata-rata tingkat kecukupan zat gizi yang cukup tinggi ternyata tidak menjamin bahwa proporsi anak yang dengan konsumsi zat gizi di bawah AKG juga rendah. Perbedaan angka rata-rata tingkat kecukupan konsumsi zat gizi dengan proporsi anak dengan konsumsi zat gizi di bawah AKG menunjukkan adanya ketimpangan antara kelompok umur area tempat tinggal, tingkat pendidkan ibu, dan kuintil.

\section{SIMPULAN DAN SARAN}

\section{Simpulan}

Rata-rata tingkat kecukupan konsumsi energi, vitamin $A$, asam folat, vitamin $C$, kalsium, dan besi masih di bawah AKG, sedangkan rata-rata tingkat kecukupan konsumsi protein dan fosfor sudah di atas AKG. Rata-rata tingkat kecukupan zat gizi yang cukup tinggi ternyata tidak menjamin bahwa proporsi anak dengan konsumsi zat gizi di bawah AKG juga rendah. Jadi rata-rata tingkat konsumsi zat gizi tidak boleh digunakan sebagai rujukan dalam mengukur kecukupan konsumsi zat gizi, karena bisa menimbulkan salah interpretasi. Proporsi anak dengan tingkat konsumsi zat gizi di bawah AKG masih tinggi dan makin tua kelompok umur, makin rendah tingkat pendidikan ibu, makin rendah kuintil dan tinggal di perdesaan makin rendah tingkat konsumsi zat gizi. Anak-anak pada kelompok umur lebih tua, tinggal di perdesaan, tingkat pendidikan ibu rendah, dan kuintil rendah, mempunyai risiko lebih tinggi konsumsi zat gizi di bawah AKG.

\section{Saran}

Upaya peningkatan konsumsi zat gizi pada anak umur 6 bulan sampai dengan 12 tahun perlu memperhatikan konsumsi energi, vitamin $A$, asam folat, vitamin $C$, kalsium, dan zat besi yang masih di bawah AKG. Selain itu perlu perhatian terhadap kelompok umur anak yang lebih tua, yang lebih berisiko kekurangan. Untuk itu perlu dilakukan upaya peningkatan kualitas dan kuantitas makanan anak.

\section{UCAPAN TERIMA KASIH}

Penulis menyampaikan terima kasih kepada FrieslandCampina, dan Frisian Flag Indonesia.

\section{RUJUKAN}

1. Badan Litbang Kesehatan. Riset Kesehatan Dasar 2013. Laporan Nasional Jakarta: Badan Litbang Kesehatan. 2013.

2. UNICEF. Improving Child Nutrition: The Achievable Imperative for Global Grogress. Geneva: UNICEF. 2013. Diakses 10 September 2013. Available from: www.unicef.org/publication/index.html. 
3. Black RE, Allen LH, Bhutta ZA. Caulfield LE, de Onis M, Ezzati M, Maternal and child undernutrition: global and regional exposures and health consequences. Lancet. 2008; 371: 243-60.

4. Badan Litbang Kesehatan. Riset Kesehatan Dasar. Laporan Nasional. Jakarta: Badan Litbang Kesehatan. 2010.

5. Damastuti E, Ariyani WD, Santoso M, Kurniawati S, Syahfitri WYN. Micronutrient Daily Intake of Elementary School Children in Bandung as Determined by UsingNAA and AAS Methods. Atom Indonesia. 2011; 37(2): 62 - 70

6. Arifin SU, Mayulu N, Rottie J. Hubungan Asupan Zat Gizi Dengan Kejadian Anemia Pada Anak Sekolah Dasar Di Kabupaten Bolaang Mongondow Utara. E-journal keperawatan (e-Kp). 2013; 1(1):8-15.

7. Lestari ED, Hartini TNS, Hakimi M, Surjono A. Nutritional status and nutrient intake fromcomplementary foods among breastfed children in Purworejo District, Central Java, Indonesia. Paediatrica Indonesiana. 2005; 45(1-2): 12-22.
8. International Children's Center Paris. The ongoing evaluation of protein energy malnutrition. Paris: Children's Center, 1984.

9. Whitney EN, Rolfes SR. Understanding Nutrition. Eighth Edition. London: Thomson Learning. 1999.

10. Puslitbang Gizi dan Makanan. Program Nutrisoft Konsumsi Makanan. Bogor: Puslitbang Gizi dan Makanan. 2008.

11. Mahmud MK, Hermana, Zulfianto NA, Rozanna, Rossi, Ngadiarti I, Hartati, B. Tabel Komposisi Pangan Indonesia (TKPI) Jakarta: Elex Media Komputindo. 2008

12. Lembaga IImu Pengetahuan Indonesia. Ketahanan pangan dan gizi di era otonomi daerah dan globalisasi. Dalam Prosiding Widyakarya Pangan dan Gizi VIII Jakarta, 17-19 Mei 2004.

13. Elhisadi TA. Food and Nutrients Intake among Libyan School Children. Science Journal of Medicine and Clinical Trial. Diakses 17 Februari 2013 melalui http://www.sjpub.org/sjmct.html. 
